\title{
Group Blogs as Toolkits to Support Learning Environments in Statistics Subject: A Qualitative Case Study
}

\author{
Mohamad Hisyam Mohd Hashim \\ Faculty of Technical and Vocational Education \\ Universiti Tun Hussein Onn Malaysia (UTHM) \\ 86400 Parit Raja, Batu Pahat, Johor, Malaysia
}

Tel: 13-777-0161Ｅ-mail: mhisyam@uthm.edu.my

Received: January 19, 2012

Accepted: January 31, 2012 Published: May 17, 2012

doi:10.5539/ies.v5n3p199

URL: http://dx.doi.org/10.5539/ies.v5n3p199

\begin{abstract}
In this paper, we describe the introduction of blogs to a class of Masters in Technical and Vocational Education students taking the MBE 1223 Statistics in Education module in Universiti Tun Hussein Onn Malaysia (UTHM). The purpose of the analysis is to elaborate on the perception of the participants towards blogs before, during and after training regarding the usefulness of their class blog. For the purpose of this study, participants will be required to handle their weekly reflective journals or their learning logs using their class blogs instead of handing them in hard copy weekly. Participants will be encouraged to blog and to provide feedback to their classmates' comments. Respondents will be required to reflect on lessons weekly and to write their reflections on the class blog. They were also required to reflect on their use of the technology in their module.
\end{abstract}

Keywords: Blog, Collaborative, Reflective, Statistics training

\section{Introduction}

The design of learning environments utilizing blogs is an emerging area for research. Blog is a website where entries are made in journal style with entries displayed in reverse chronological order, meaning the most recent entries at the top of the page to allow readers to see the latest blog entry first. "Blogging" refers to the act of writing to or interacting with a blog and one who blogs is called a "blogger". The illiterate of the 21st century will not be those who cannot read and write, but those who cannot learn, unlearn, and relearn.

While there has been a lot of study on the usage of blogs and wikis in other countries, little research has been done to incorporate the use of blogs in classrooms in Malaysia. There are still considerably low level practices of online teaching and learning method in most of the Institutions of Higher Learning in Malaysia. Nevertheless, there have been some efforts being done by organizations or by lectures themselves. One of the methods currently in practice is communication through blogs that have been developed by lectures themselves. The use of the Learning management System (LMS) are being adopted by some Universities namely, the University Tun Hussein Onn (UTHM), the University Sains Malaysia (USM), and the University Pendidikan Sultan Idris (UPSI). However, the usage of online teaching and learning is limited since it is still being considered as a new method.

According to Williams and Jacobs (2004), higher education is beginning to explore the potential educational value of blogs as means to promote deeper learning and integration of learning experiences from inside and outside the classroom. Blogs appear to be used as a collaborative or reflective space to support students' reflection on resources and content (Dron, 2003; Williams \& Jacobs, 2004). Blogs are also being used in education especially as group blogs for pupil-to-pupil communication and display of work, a tool for student portfolio and classroom management tool and for reflective learning and peer support (Hall and Davidson, 2007). Duffy and Bruns (2006) further add that tools like blogs and RSS (a format for syndicating news and content) enable content editing collaboratively, peer assessment, formative evaluation of the end product, individual as well as group reflection on learning experiences and user-centric latest information regarding changes in collaborative work spaces. Sessums (2005) believes that if the collaborative environment is structured to provide regular feedback and allows the exchange of opinions, hence, there is a possibility that the reflective thinking will more likely be constructive and meaningful. Researches in the field of E- Learning show that there are three problems that have been identified. Firstly is the lack of students' collaborative learning skills. Secondly, the education programs for teacher itself do 
not require teacher to effectively utilize technologies in the classroom. The third problem is the lack of reflective activities in teacher education programs.

\subsection{Purpose of Study}

The aim of this study is to explore, to understand and to explain the usage of Blog in the learning of Statistic subject. For the purpose of this study, participants will be required to handle their weekly reflective journals or their learning logs using their class blogs instead of handing them in hard copy weekly. The main idea of the study will be to facilitate me to get a deep understanding of the data collected from the interviews, field notes and blog posts and subsequently to make interpretations for the following research questions: What are the perceived usefulness of the class blog by the participants? What are the problems that the participants encountered when they used the class blog?.

\section{Literature Review}

The issue of lack of students' collaborative learning skills students as mentioned by Pallofff and Pratt (2005a) is an important challenge as some students do not know how to collaborate or refuse to participate and collaborate. This may be because students pursuing higher education have acquired their own study ways and are strongly concerned with their personal achievement (Panitz, 2006). A collaborative environment also should be able to allow peers to be seen as valuable sources of knowledge and ideas; a connection that participants can rely on beyond any formal classroom structure, i.e., collaboration leading to a community of interest (Sessums, 2005).

Collaborative work contributes to reflective practices. Reflective writing that includes self-assessment and pushes the writer to deeper self-knowledge is widely considered central to teachers' development and improvement (Davis and Waggett, 2006). However, the enthusiasm to include reflective learning across education has not reached consensus across the teacher education community (Rodgers, 2002; Lee, 2005). Newell (1996) mentioned that it is important for pre-service teachers to experience collaboration and reflection in university teacher education courses if teachers are to use it in their own classrooms. Teacher education programs need to embrace educational technology and help prospective teachers use it effectively in the classroom (Chan and Ridgway, 2005; National Education Association, 2006 and Coutinho, 2007). However, it seems that teacher education programs do not prepare them for an effective use of technologies in the classrooms.

Newell (1996) also mentioned that it is important for pre-service teachers to experience collaboration and reflection in university teacher education courses if teachers are to use in their own classrooms. Hence, there is a need incorporate collaborative group work to provide these students the chance to develop skills in team work, participative decision-making and time management (Moore, 2006).

\section{Methodology}

In order to obtain participants for the research, I discussed with one of the instructors of the Statistics in Research (MBE 1223) module of the university who was very interested to be part of the project and was interested to incorporate new technologies in the teaching of Statistics. Hence, the participants of this research will be pre-service lecturers taking the MBE 1223 module taught by this instructor. The Statistics module is also chosen as statistics instruction ought to resemble statistical practice which is viewed as being collaborative in nature (Ben-Zvi, 2007) and (Roseth, Grafield and Ben-Zvi, 2007). For the purpose of this study, participants will be required to handle their weekly reflective journals or their learning logs using their class blogs instead of handing them in hard copy weekly. Participants will be required to reflect on lessons weekly and to write their reflections on the class blog as part of their assignment. Participants will also be encouraged to blog and to provide feedback to their classmates' comments. They will also be required to reflect on their use of both the technologies in their module.

Methods of data collection will be of two types: interactive and non-interactive. By using both interactive and non-interactive methods, a richer database is possible because of the greater variety of constructs resulting from these kinds of data. In addition, interactive and non-interactive methods are sufficiently different from one another that they can be used for triangulation and thus may provide a means of determining internal validity (Ratcliff, 1999).The methods used to collect data will be as follows: (1) Preliminary survey of the participants and their computer skills using questionnaires a week before the training sessions (non-interactive); (2) observation of the training sessions where the pre-service lecturers were taught how to use the class blog for the first time by the researcher. All this moments were video taped (interactive); (3) documental analysis of all written materials produced by participants, including the blog posts and comments, and also the researcher's written reflections and field notes (non-interactive); (4) individual interviews to be conducted with the participants right after the training at the beginning of the semester (interactive). 
We went through the blog posts and comments looking for things pertinent to answering the research question as the research questions will tell us what pieces need to be coded and what to leave by the wayside for another question.

\section{Findings and Discussion}

What are the Perceived usefulness of the class blog by the participants?. The usage of Blog is one of the methods in teaching and learning of Statistic subject. This application of blog in learning statistic might have resulted increase in understanding of the subject for the students. It might also have caused decline in students' understanding of the subject. Since it is fairly a new practice, researchers believe that there are still few things that need to be improved so that students will be able to derive benefits from using blog and increase their understanding of the subject. Studies have shown that, (1) Student eager to learn about blog and Need trainer and the training manual.; (2) Some prior knowledge and Computer skill; (3) The time constraint, lukewarm response and too afraid to comment; (4) Emphasis on the Class Blog, Not Informed and the Confusion.

\subsection{Eager to Learn about Blogs and Need Trainer and Training Manual}

Nowadays, Blog has been popularly used as a tool. Blog has been used by Statistic students as one of their method of learning. It is learnt that, most of them are stongly interested and enjoyed using the Blog. They were very interested in learning the capability of the blog and also eager to explore it so that it can be practiced.

I was excited and curious to know what blog is all about. I was excited because it is something new for me. It contributes to new knowledge. I don't think I will be able to use the blog today without the training manual provided. Maybe some of us will slack if the trainer did not provide the training manual. I will be lost without the training manual. I needed to see it shown to me live.

The presence of the trainer and the training manual was a winning combination to introduce the class blog. The Blog is a new thing and new knowledge for them. Therefore, they are keen to learn about the blog in details and profoundly.

\subsection{Some Prior Knowledge and Computer Skills}

Students do not know the way to obtained a blog that can be used in their learning process. Nevertheless, they have the initiative to develope blogs of their own. Learning process using blogs could assit students to understand a new method in learning.

I don't know how to use, setup or apply a blog. I don't know how blogs can be applied in educational setting. For now, I don't know how to create my own blog, I don't have any idea on how to do it. Will it be easy? Will it be hard? How to setup one? I don't know anything, right?. I don't have time to create a blog; I only read other people's blog. Even though I could not understand everything during the initial training, I will just take the basic and explore myself. This is because I am used to using the Internet. The blog has tools like a word processor which I am familiar with and this makes it easier for us. We still need a lot of practice (on contributing to the blog

The participants' had basic computer skills and were familiar with internet and word processors which made it easier for them to adapt to blogs. The issue of lack of students' collaborative learning skills students as mentioned by Pallofff and Pratt (2005a) is an important challenge as some students do not know how to collaborate or refuse to participate and collaborate. They do not have the ample time and adequate knowledge to create their own blog. Furthermore, they do not know how to interact with others through the blog. They only capable of reading what are written in the blog without being able to actually reflect on it interactively. The presence of the trainer and the training manual was a winning combination to introduce the class blog.

\subsection{The Time Constraint, Lukewarm Response and too Afraid to Comment}

The participants faced constraints in posting blog posts and comments in their class blog. Six major inherent problems were identified. The first constraint highlighted by several participants was the time constraint they faced.

I only check the blog each time I need to hand in the reflective journal. Initially, I checked the class blog every day and there was not much response. Even if I post I feel no one else reads except for Khairul. I feel I am actively participating in the class blog, even though I don't post every day. But, there is not much of feedback (received from other classmates.

The third constraint to blog participation was too afraid to comment on other classmate's post. 
I am afraid to (post a) comment on (post of other classmates) others in case they take my comments personally. Maybe more people should do more than just post their reflective journals. We can ask them to post any comments maybe some of them will add something new to it and it won't be the same as the other posts.

However, two participants highlighted that the comments on other people posts should be encouraged.

\subsection{Emphasis on the Class Blog, Not Informed and the Confusion}

The fourth constraint to blog participation was when the instructor initially did not put much emphasis on the class blog participation.

The class instructor initially told us to contribute to the class blog only if we had the time, so this may make other classmates to feel that this (class blog participation) is not that important. I have posted at the wrong place. I posted the reflective journal at the comments, but my housemates later told me that I posted at the wrong place.

The fifth constraint was the confusion on where to post their reflective journals despite the trainer creating a special page for posting the weekly reflective journals. The sixth constraints were that all the participants were not informed about new blog posts and comments at their class blog via e-mail. Only the researcher received the email in case of any updates.

During class, there were still many of them that didn't know about it. I have already mentioned in my post at the main page. They still asked about it in class despite it has been mentioned in the class blog. So, they are not alert.

This was troublesome to the participants as they have to check the class blog often for any updates. Participants' were less aware to new blog post and comments due to no notification given. One participant explained that he had posted about a correction of information during the class discussion but many were still unaware of the blog posts.

\subsection{The Problems that the Participants Encountered When They Used the Class Blog}

The absence of RSS enabled class blog has affected the participants to know the latest updates at their class blogs. Another example was when many participants were not aware that the trainer had posted about how to solve the login problem some students faced during the training.

Oh, I haven't seen that post. My comment on this class blog is the words such as Log In and Log Out are difficult to find. It is also difficult to read the comments given because there is no clear difference between in terms of the colour of the fonts or the size of the fonts to differentiate between comments. One more thing is, the space to enter comments is little and the writing is very small. What else I can see from the blog posts is, there are many typo errors made by my classmates.

Finally, another weakness was the appearance of the blog itself. These constrain or problems were the main causes that deter motivation of students to participation in class blog.The participants were in consensus about the need for the class instructor to participate in the class blog. The following opinions illustrate the case in point:

I think the class instructor must post at least something. Once the instructor posts something, it will surely make a difference. We will feel closer to the instructor if the instructor can post on the blog and give her comments. The instructor has been supervising us in terms of our participation in class. Our instructor mentioned before after the first week that 6 students did not post their reflective journal and wanted them to post soon. I think the supervision is essential

However, one participant felt that the instructor has been supervising them even though there are not many blog posts or comments from her as she has mentioned in class regarding the students' participation. Despite the challenges highlighted, some participants believed that handing in a reflective journal weekly via the class blog benefits them:

The reflective journal contains information about our studies and is helpful..It is easier to hand in the journal. It's convenient. It makes the learning process easier as it enables discussion and handing in the reflective journal. Handling the reflective journals via the class blog enables us to save money, time and it is more systematic.

The participants interviewed were honest and open and demonstrated tremendous enthusiasm to explore the class blog. Their readiness to admit lack of knowledge about blogs allowed the researcher to motivate them to get used to the class blog's functionalities. The above mentioned constraints is also supported by Foo Sze-yeng and Raja 
Maznah Raja Hussain (2006) also found that there are various factors that influences the level of reflection such as students perception of reflection, attitude towards web logging, peer support, instructor and instruction, audience, time and assessment.

\section{Conclusions}

Instructor must participate in the class blogs by providing feedback through blog posts and comments. Trainer must setup the class blog with participants personal e-mail addresses to ensure that participants receive blog updates through RSS in their e-mail inbox. Participants must try to find time to blog and try to participate actively in their class blog by using the class blog functionalities to the maximum. It is recommended that this study be conducted using individual blogs for every participant. Accordingly, it is recommended that a study to develop and validate an instrument for measuring blog usefulness in a classroom setting be conducted. It is recommended that a comparative study be conducted to determine the perceived usefulness of group blogs across different subject modules.

\section{References}

Ben-Zvi, D. (2007). “Using Wiki to Promote Collaborative Learning in Statistics Education”. [electronic version]. Technology Innovations in Statistics Education, 1(1), Article 4. [Online] Available: http://repositories.cdlib.org/uclastat/cts/tise/vol1/iss1/art4 (November 5, 2007)

Chan, K. K., \& Ridgway, J. (2005). “Blog: a tool for reflective practice in teacher education?” Paper presented at the 3rd International Conference on Education and Information Systems: Technologies and Applications, Orlando, 333-337. [Online] Available: www.dur.ac.uk/resources/smart.centre/Publications//BlogsFloridaeista2005.pdf (October 1, 2007)

Coutinho, C. M. P., \& Bottentuit Junior, J. B. (2007). "Collaborative Learning Using Wiki: A Pilot Study With Master Students In Educational Technology In Portugal”. Proceedings of World Conference on Educational Multimédia, Hypermedia e Telecommunications (ED-MEDIA). pp. 1786-1791. [Online] Available: https://repositorium.sdum.uminho.pt/bitstream/1822/6720/1/Edmedia2007.pdf (December 30, 2007)

Davis, M., \& Waggett, D. (2006). "Enhancing Pre-service Teachers' Reflective Practice via Technology Competencies and ePortfolio Development”. In C. Crawford et al. (Eds.), Proceedings of Society for Information Technology and Teacher Education International Conference 2006 (pp. 3106-3107). Chesapeake, VA: AACE. Retrieval date: 8 January 2008

Dron, J. (2003). "The Blog and the Borg: a Collective Approach to E-Learning," presented at E-Learn 2003, Phoenix, Arizona, 2003. [Online] Available: http://www.cmis.brighton.ac.uk/staff/jd29/papers/drone learn2003short.doc (January 8, 2008)

Duffy, P., \& Bruns, A. (2006). "The Use of Blogs, Wikis and RSS in Education: A Conversation of Possibilities". [electronic version]. Proceedings Online Learning and Teaching Conference 2006, pages pp. 31-38, Brisbane. [Online] Available: http://eprints.qut.edu.au (December 19, 2007)

Foo Sze-yeng \& Raja Maznah Raja Hussain. (2006). "Reflective learning through weblogging”. 1st International Malaysian Educational Technology Convention, 773-780

Hall, H., \& Davidson, B. (2007). "Social software as support in hybrid learning environments: The value of the blog as a tool for reflective learning and peer support". [electronic version]. Journal of Library and Information Science Research, 29, p.p. 163-187. Retrieval date: 12 October 2007

Lee, H. J. (2005). "Understanding and assessing preservice teachers' reflective thinking”. [electronic version]. Journal of Teaching and Teacher Education, 21, 699-715.

Moore, C. (2006). Integrating the Development of Effective Collaboration and Communication Skills for Dynamic Business Environments. [Online] Available: www.lilydale.swinburne.edu.au/forum/documents/c_moore.pd (November 22, 2007)

National Education Association (2006). [electronic version]. NEA Positions on Technology and Education. [Online] Available: http://www.nea.org/technology/index.html (January 8, 2008)

Newell, S.T. (1996). Practical inquiry: Collaboration and reflection in teacher education Reform. [electronic version]. Journal of Teaching and Teacher Education. 12(6). Pages 567-576. http://dx.doi.org/10.1016/S0742-051X(96)00001-7. (January 18, 2008).

Palloff, R. M., \& Pratt, K. (2005a). “Collaborating Online - Learning Together in Community”, San Francisco: Jossey-Bass, 1st edition. pg 9 
Panitz, T. (2006). "Why More Teachers Do Not Use Collaborative Learning Techniques”. [Online] Available: http://home.capecod.net/ tpanitz/tedsarticles/whyfewclusers.htm. (October 3, 2007)

Ratcliff, D.E. (1999). “An elementary school hallway: social formations and meanings outside the classroom”. University of Georgia: Ph.D Dissertation. [Online] Available: http://qualitativeresearch.ratcliffs.net (March 3, 2008)

Rodgers, C. (2002). "Defining reflection: Another look at John Dewey and Reflective Thinking”. Teachers College Record, 104(4), 842-866. [online version] Retrieval date: 3 March 2008

Roseth, C.J., Garfield, J. B., \& Ben-Zvi, D. (2007). “Collaboration in Learning and Teaching Statistics”. [electronic version]. Journal of Statistics Education. 16(1). [Online] Available: www.amstat.org/publications/jse/v16n1/roseth.html (March 3, 2008)

Sessums, C. D. (2005). "Collaboration and Teacher Reflection”. [Online] Available: http://eduspaces.net/csessums/weblog/3762.html (March 14, 2008)

Williams, J.B., \& Jacobs, J. (2004). "Exploring the use of blogs as learning spaces in the higher education sector". [electronic version]. Australasian Journal of Educational Technology, 20(2), 232-247. Retrieval date: 18 September 2007 